Jurnal Keperawatan Silampari

Volume 1, Nomor 2, Juni 2018

e-ISSN : 2581-1975

p-ISSN : 2597-7482

DOI: https://doi.org/10.31539/jks.v1i2.97

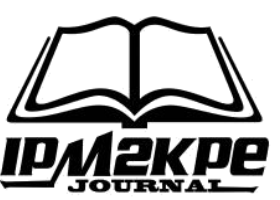

\title{
PENGARUH EDUKASI PENDEKATAN SPIRITUAL BERBASIS VIDEO TERHADAP KEPATUHAN PEMBATASAN CAIRAN KLIEN ESRD YANG MENJALANI HEMODIALISA
}

\author{
Andri Kusuma Wijaya ${ }^{1}$, Busjra Busjra ${ }^{2}$, Rohman Azzam ${ }^{3}$ \\ Program Studi Magister Keperawatan, Universitas Muhammadiyah Jakarta 1,2,3 \\ andrikusuma76@yahoo.com ${ }^{1}$
}

\begin{abstract}
ABSTRAK
Tujuan penelitian ini untuk mengetahui pengaruh edukasi dengan pendekatan spiritual berbasis video terhadap kepatuhan pembatasan cairan atau interdialysis weight gain pada klien End Stage Renal Disease yang menjalani terapi hemodialisa. Desain penelitian yang digunakan pra eksperimental one-group pretest-posttest. Hasil penelitian menunjukkan adanya perbedaan rata-rata Interdialysis Weight Gain setelah dilakukan edukasi dengan pendekatan spiritual berbasis video ( $p$ value $=0,011 ;$ ). Sementara terbukti ada hubungan antara dukungan keluarga ( $p$ value $=0,047$ ) dengan kepatuhan pembatasan cairan atau interdialysis weight gain, sedangkan usia ( $p$ value $=$ $0,364)$, tingkat pendidikan $(p$ value $=0,949)$ tidak ada hubungan dengan kepatuhan pembatasan cairan atau interdialysis weight gain. Simpulan, edukasi dengan pendekatan spiritual dapat meningkatkan kepatuhan pembatasan cairan pada klien yang menjalani hemodialisa.
\end{abstract}

Kata Kunci: End Stage Renal Disease (ESRD), Spiritual Berbasis Video

\begin{abstract}
The purpose of this study was to determine the effect of education with a video-based spiritual approach to compliance with fluid restriction or interdialysis weight gain in End Stage Renal Disease clients undergoing hemodialysis therapy. The research design used was pre-experimental one-group pretest-posttest. The results showed a difference in the average Interdialysis Weight Gain after education with a video-based spiritual approach ( $p$ value $=0.011 ;)$. While there is a proven relationship between family support ( $p$ value $=0$, 047) with adherence to fluid restriction or interdialysis weight gain, while age ( $p$ value $=0.364)$, education level $(p$ value $=0.949)$ has no relationship with adherence to fluid restriction or interdialysis weight gain. Conclusion, education with a spiritual approach can improve compliance with fluid restrictions in clients undergoing hemodialysis.
\end{abstract}

Keywords: End Stage Renal Disease (ESRD), Spiritual Based Video 


\section{PENDAHULUAN}

End Stage Renal Disease (ESRD) adalah gangguan fungsi ginjal yang progresif dan irreversible, dimana kemampuan tubuh gagal untuk mempertahankan keseimbangan cairan dan elektrolit sehingga menyebabkan uremia (Smeltzer, Bare, 2008). Berdasarkan data riskesdas (2013) menunjukkan prevalensi end stage renal disease di Indonesia sebesar 0,2 \%. Prevalensi tertinggi di Sulawesi Tengah sebesar 0,5 $\%$, diikuti Aceh, Gorontalo, dan Sulawesi Utara masing-masing 0,4 \%. Sementara Nusa Tenggara Timur, Sulawesi Selatan, Lampung, Jawa Barat, Jawa Tengah, Yogyakarta, dan Jawa Timur masing-masing 0,3\%. Untuk provinsi Bengkulu, Jambi, Sumatera Utara, Sumatera Barat, Banten, Bali, Kalimantan Barat masing-masing 0,2 \%.

Pada klien end stage renal disease penanganan dapat dilakukan dengan berbagai jenis fasilitas layanan yang sesuai dengan keinginan dan kemampuan klien. Menurut data Pernefri (2012) dijelaskan bahwasanya jenis fasilitas layanan yang di berikan oleh renal unit adalah layanan hemodialisa (78\%), transplantasi (16\%), Continous Ambulatory Peritoneal Dialysis (CAPD) (3\%), Continuous Renal Replacement Therapy (CRRT) (3\%). Jumlah klien baru dan klien aktif yang menjalani terapi hemodialisa terus mengalami peningkatan dari tahun ketahun. Pada tahun 2007 jumlah klien baru 4977 dengan klien aktif sejumlah 1885, tahun 2008 jumlah klien baru 5392 dengan klien aktif sejumlah 1936, tahun 2009 jumlah klien baru 8193 dengan klien aktif sejumlah 4707, tahun 2010 jumlah klien baru 9649 dengan klien aktif sejumlah 5184, tahun 2011 jumlah klien baru 15353 dengan klien aktif sejumlah 6951, tahun 2012 jumlah klien baru 19621 dengan klien aktif sejumlah 9161. Jumlah klien laki-laki setiap tahunya melebihi jumlah klien perempuan.

Klien dengan end stage renal disease yang menjalani terapi hemodialisa dapat mengalami Interdialytic Weight Gain (IDWG) atau ketidakpatuhan dalam pembatasan asupan cairan yang disebabkan oleh ketidakmampuan fungsi ekskresi ginjal, karena jumlah nefron yang berfungsi menurun, sehingga GFR total menjadi menurun yang menyebabkan terjadinya kelebihan cairan yang dimanifestasikan dengan IDWG (Blacks \& Hawk, 2014). IDWG atau ketidakpatuhan dalam pembatasan asupan cairan ini dihitung berdasarkan berat badan kering (dryweight, yaitu berat badan post dialysis setelah sebagian besar cairan dibuang melalui proses ultrafiltrasi (Reams \& Elder, 2003). Untuk mengatasi IDWG yang disebabkan oleh asupan cairan yang berlebihan maka dapat dilakukan tindakan pembatasan cairan. Pembatasan cairan mempunyai tujuan untuk mengurangi kelebihan cairan pada periode interdialitik.

Kelebihan cairan dapat menyebabkan edema dan hipertensi, hipertropi ventrikuler kiri dan juga berhubungan dengan mortalitas klien (Ifudu et al 1997 dalam Istanti 2014). Kepatuhan klien terhadap pembatasan cairan merupakan hal yang sangat berperan untuk mencegah terjadinya IDWG. Menurut penelitian Kugler (2005) tentang ketidakpatuhan klien terhadap diet dan pembatasan cairan pada dewasa yang menjalani terapi hemodialisa didapatkan hasil masih banyak klien yang memiliki ketidakpatuhan terhadap pembatasan cairan sebesar (74,6\%). Penelitian Wahyudi, Fitri (2012) menjelaskan ada hubungan kepatuhan diet dengan IDWG sebelum melakukan terapi hemodialisa dimana hubungan tersebut dapat diartikan semakin tinggi kepatuhan maka semakin turun IDWG sebelum terapi hemodialisa. Menurut penelitian Kamaluddin \& Rahayu (2009) faktor-faktor yang dapat mempengaruhi kepatuhan pembatasan cairan adalah faktor pendidikan, pengetahuan klien serta keterlibatan tenaga kesehatan.

Sehingga perlu diperhatikan faktor-faktor dalam pembatasan asupan cairan yang merupakan usaha perawat dalam memotivasi klien agar mematuhi pembatasan asupan 
cairan. Usaha perawat dapat berupa sistem yang didasarkan pada peran perawat dalam memenuhi kebutuhan akan perawatan diri klien atau self care termasuk dalam pembatasan asupan cairan. Self care merupakan teori keperawatan yang menekankan pada kemampuan individu untuk memenuhi kebutuhan self care secara mandiri sehingga klien dapat menjadi agen self care bagi dirinya sendiri (Hidayati, 2013). Keterlibatan tenaga kesehatan termasuk perawat dalam memenuhi kebutuhan self care klien dapat dilakukan dengan memberikan pengetahuan dalam bentuk pendidikan kepada klien. Pendidikan kesehatan adalah suatu proses yang direncanakan untuk mempengaruhi atau mengajak orang lain, baik individu, kelompok atau masyarakat agar melaksanakan perilaku hidup sehat (Nursalam, Efendi, 2008). Hal ini sejalan dengan penelitian Hanum, dkk (2015) tentang pengaruh edukasi secara individual tentang pembatasan asupan cairan terhadap pengetahuan tentang pembatasan cairan dan IDWG pada klien hemodialisa didapatkan hasil ada pengaruh edukasi tentang pengetahuan pembatasan asupan cairan dengan IDWG.

Edukasi telah biasa dilakukan oleh perawat sebagai salah satu intervensi yang diberikan kepada klien, akan tetapi edukasi masih dilakukan secara konvensional dengan menggunakan media berupa leaflet, booklet, dan flip chart sedangkan pendidikan kesehatan dengan menggunakan media audio visual seperti video masih sangat jarang digunakan khususnya edukasi tentang pembatasan cairan. Edukasi yang sering kali diberikan oleh perawat untuk mengatasi masalah klien lebih banyak berfokus pada aspek yang bersifat fisikal, padahal perawat juga memiliki tanggung jawab untuk memberikan edukasi pada aspek lainya termasuk psikologis dan spiritual. Usaha pendidikan kesehatan yang diberikan harus menyertakan nilai psikososial, spiritual dan budaya yang dimiliki oleh klien (Potter, Perry, 2010). Oleh karena itu edukasi dengan pendekatan spiritual dirasakan sangat penting diberikan untuk meningkatkan kepatuhan klien dalam pembatasan cairan.

Menurut Walton (2002) spiritualitas dapat memberikan kekuatan hidup dari dalam diri yang akan menginspirasi seseorang untuk berjuang mendapatkan keseimbangan dalam hidup. Spiritual juga mampu memberikan pemahaman tentang bagaimana mempengaruhi kehidupan klien yang menjalani terapi hemodialisa untuk meningkatkan derajat kesehatanya. Spiritualitas mengacu pada bagaimana menjadi manusia yang mencari makna melalui hubungan intra, inter, dan transpersonal. Spiritualitas secara umum melibatkan keyakinan dalam hubungan dengan sesuatu yang lebih tinggi, berkuasa, memiliki kekuatan mencipta, dan bersifat ketuhanan, atau memiliki energi yang tidak terbatas (Kozier, et.al, 2011). Menurut Florence Nightingale dalam Potter, Perry (2010) melayani kebutuhan spiritual sama pentingnya dengan melayani kebutuhan fisik.

Kesehatan seseorang tergantung pada keseimbangan faktor fisik, psikologi, sosiologi, budaya dan spiritual. Spiritualitas yang positif akan mempengaruhi dan meningkatkan kesehatan serta sebagai kegiatan pencegahan penyakit (Aaron et. al, 2003 dalam Potter, Perry, 2010). Sedangkan menurut penelitian Suratih dkk, (2014) tentang pengaruh bimbingan spiritual Islami terhadap kualitas hidup klien yang menjalani terapi hemodialisa di RSUD Kabupaten Semarang terdapat perbedaan kualitas hidup klien yang tidak dan yang diberikan bimbingan spiritual Islami. Oleh karena itu pemberian spiritual dapat meningkatkan kualitas hidup karena merasakan perasaan yang nyaman dan tenang. Hal ini sejalan dengan penjelasan Grassley (2012) bahwa perawatan secara spiritual dapat membuat suasana klien menjadi lebih nyaman dan tenang. 
Sehingga melalui edukasi dengan pendekatan spiritual diharapkan dapat mengurangi komplikasi yang terjadi pada klien end stage renal disease yang menjalani terapi hemodialisa seperti ketidakpatuhan dalam pembatasan asupan cairan yang akan berdampak buruk terhadap kesehatan sehingga klien mampu mengambil keputusan untuk patuh terhadap pembatasan cairan. Penambahan nilai interdialytic weight gain yang terlalu tinggi atau ketidakpatuhan dalam pembatasan asupan cairan akan menimbulkan efek negatif terhadap keadaan klien, diantaranya kram otot, hipertensi, sesak nafas, mual dan muntah, dan lainnya (Brunner, Suddarth, 2005). Oleh karena itu pengambilan keputusan untuk patuh terhadap pembatasan cairan penting dalam hal ini. Spiritual akan membuat klien memiliki kemampuan untuk menemukan kekuatan batiniah yang dinamis, kreatif yang diperlukan saat membuat keputusan sulit. Kekuatan batiniah merupakan suatu sumber energi yang menanamkan harapan, memberikan motivasi dan mempromosikan harapan yang positif di dalam kehidupan (Potter, Perry, 2010).

Edukasi dengan pendekatan spiritual, diharapkan dapat berhasil merubah pemahaman klien terkait dengan pembatasan cairan. Untuk mencapai keberhasilan tersebut perawat harus memahami sepenuhnya materi yang akan diberikan serta media yang dipilih perawat diharapkan dapat membantu klien dalam memperoleh pengetahuan dan informasi yang mudah dimengerti. Salah satu usaha untuk mengatasi keadaan demikian ialah penggunaan media. Fungsi media dalam kegiatan tersebut disamping sebagai penyaji stimulus informasi, sikap, juga untuk meningkatkan keberhasilan dalam menerima informasi (Hariyadi, 2012).

Fenomena yang ditemukan peneliti di RSUD Curup Kabupaten Rejang Lebong berdasarkan data dari RSUD Curup Kabupaten Rejang Lebong jumlah klien yang menjalani terapi hemodialisa pada tahun 2014 sejumlah 53 klien sedangkan pada tahun 2015 klien yang menjalani terapi hemodialisa sejumlah 70 klien. Survey awal peneliti pada bulan Februari 2016 di Unit Hemodialisa RSUD Curup Kabupaten Rejang Lebong di dapatkan klien dengan interdialytic weight gain $>5,7 \%$ sejumlah 22 klien. Menurut keterangan dari kepala unit hemodialisa penanganan yang diberikan pada klien end stage renal disease hanya fokus pada kesejahtraan fisik sedangkan kesejahtraan spiritual belum mendapatkan perhatian yang memadai hal tersebut didasarkan dengan tidak adanya unit bimbingan rohani untuk klien rawat inap maupun rawat jalan.

\section{METODE PENELITIAN}

Desain penelitian yang digunakandalam penelitian ini adalah dengan desain praexsperimental one group pretest-posttest dengan populasi seluruh klien yang menjalani terapi hemodialisa. Penentuan jumlah sampel dengan menggunakan tehnik sampling jenuh atau total sampling yang dibatasi dengan kriteria tertentu. Adapun kriteria sampel antara lain; (1) kriteria inklusi; klien ESRD yang masuk kategori tidak patuh terhadap pembatasan cairan dengan IDWG $>5,7 \%$, bersedia menjadi responden, mampu membaca dan menulis serta beragama islam. Sedang (2) kriteria eksklusi; Klien yang tidak kooperatif, klien yang harus disegerakan tindakanya atau cito, klien yang mengundurkan diri, serta klien dengan gangguan jiwa. Total jumlah responden dalam penelitian ini 22 responden.

Prosedur pengumpulan data pada penelitian ini meliputi berbagai tahapan mulai dari prosedur administratif dengan cara mendapatkan surat keterangan lolos kaji etik serta mendapatkan perijinan untuk penelitian di Rumah Sakit Umum Daerah Curup Kabupaten Rejang Lebong. Prosedur teknis yang dilakukan dalam penelitian ini dengan 
cara meminta izin kepada penganggung jawab ruangan hemodialisa dan mensosialisasikan maksud dan tujuan penelitian kepada tim keperawatan. Langkah selanjutnya peneliti melakukan seleksi terhadap calon responden dengan berpedoman kepada kriteria inklusi, meminta kesediaan responden untuk menjadi sampel dengan terlebih dahulu menjelaskan maksud dan tujuan penelitian dan menandatangani lembar informed concent.

Pelaksanaan dalam penelitian ini dimulai dari tahapan pre test merupakan salah satu cara yang dilakukan untuk mengetahui kepatuhan pembatasan cairan atau interdialysis weight gain sebelum dilakukan edukasi dengan pendekatan spiritual berbasis video dengan cara melihat data sekunder (status klien) tentang interdialysis weight gain atau kepatuhan dalam pembatasan cairan. Tahapan intervensi dimana peneliti memastikan responden mengerti alasan dilakukan edukasi dengan pendekatan spiritual berbasis video. Peneliti memberikan edukasi dengan pendekatan spiritual berbasis video di rumah sakit pada saat kunjungan melakukan terapi hemodialisa. Responden diposisikan senyaman mungkin bisa dengan baring atau duduk diatas tempat tidur. Kemudian peneliti membuka acara dengan menjelaskan kembali tujuan dan pokok-pokok materi dari penelitian serta melakukan pemutaran video yang berisi edukasi dengan pendekatan spiritual yang diputarkan dengan bantuan alat proyektor audio visual.

Melakukan evaluasi terkait video yang telah disampaikan dengan cara memberikan pertanyaan tentang materi yang telah diberikan kemudian dilanjutkan dengan memberikan kesempatan responden dan keluarga untuk bertanya tentang materi yang telah disampaikan, serta meminta responden dan keluarga agar dapat melihat, belajar, memahami kembali video yang telah diberikan dengan memutar kembali video tersebut minimal 1 kali sehari khususnya selama 3 minggu setelah pemberian edukasidengan pendekatan spiritual berupa video. Tahap akhir membagikan video dalam bentuk $\mathrm{CD}$ dan via Bluetooth. Pelaksanaan pelaksanaan edukasi dengan pendekatan spiritual berbasis video yang dilakukan oleh responden diobservasi oleh peneliti dengan menanyakan secara langsung setiap kali kunjungan responden ke rumah sakit untuk melakukan terapi hemodialisa. Selain menanyakan langsung kepada responden apakah edukasi dengan pendekatan spiritual dilakukan atau tidak, peneliti juga menanyakan kepada keluarga responden.

Kegiatan post test dilakukan untuk mengetahui perbedaan tingkat kepatuhan pembatasan cairan atau interdialysis weight gain setelah diberikan intervensi edukasidengan pendekatan spiritual berbasis video. Post test ini diukur dengan cara melihat data sekunder (status klien) tentang interdialysis weight gainatau kepatuhan dalam pembatasan asupan cairan. 
HASIL PENELITIAN

Analisis Univariat

Tabel. 1

Distribusi Responden Berdasarkan Jenis Kelamin dan Tingkat Pendidikan

\begin{tabular}{|c|c|c|}
\hline Karakteristik Responden & $\mathrm{N}$ & Persentase (\%) \\
\hline \multicolumn{3}{|l|}{ Jenis Kelamin } \\
\hline Perempuan & 10 & 45.5 \\
\hline Laki-laki & 12 & 54.5 \\
\hline Total & 22 & 100 \\
\hline \multicolumn{3}{|l|}{ Tingkat Pendidikan } \\
\hline Rendah & 12 & 54.5 \\
\hline Tinggi & 10 & 45.5 \\
\hline Total & 22 & 100 \\
\hline
\end{tabular}

Berdasarkan tabel 1 menunjukan bahwa jenis kelamin dominan terjadi pada lakilaki dimana dari 22 klien yang berjenis kelamin laki-laki ada $12(54,5 \%)$ responden dan yang berjenis kelamin perempuan ada $10(45,5 \%)$ responden. Tingkat pendidikan didapatkan bahwa dari 22 responden sebagian besar memiliki tingkat pendidikan rendah yaitu $12(54,5 \%)$ yang berpendidikan tinggi ada $10(45,5 \%)$ responden.

Tabel. 2

Distribusi Responden Berdasarkan Usia pada Klien

\begin{tabular}{cccccc}
\hline Variabel & $\mathrm{N}$ & Mean & SD & Min-Mak & $95 \%$ CI \\
\hline Usia & 22 & 44.90 & 11.38 & $20-63$ & $39.86-49.95$ \\
\hline
\end{tabular}

Berdasarkan tabel 2 didapatkan rata-rata usia adalah 44.90 tahun dengan standar deviasi adalah 11.38. Usia termuda adalah 20 tahun dan usia tertua adalah 63 tahun. Dari hasil estimasi interval dapat disimpulkan bahwa $95 \%$ diyakini bahwa umur ratarata antara 39.86 tahun sampai dengan 49.95 tahun.

\section{Analisis Bivariat}

Analisis bivariat digunakan untuk melihat sekaligus menguji perbedaan atau tidak adanya perbedaan antara kepatuhan pembatasan cairan atau interdialytic weight gain setelah diberikan tindakan berupa edukasi dengan pendekatan spiritual. Hasil dari peneliti dapat dilihat pada tabel berikut:

Tabel. 3

Analisis Perbedaan Rata-Rata Interdialytic Weight Gain dalam Persentase Sebelum dan Sesudah Perlakuan

\begin{tabular}{|c|c|c|c|c|c|c|c|}
\hline Variabel & $\mathrm{N}$ & Mean & SD & $\begin{array}{c}\text { Rerata } \\
95 \% \text { CI }\end{array}$ & $T$ & $d f$ & $p$ Value \\
\hline Sebelum & 7 & 6.685 & 0.455 & $0.252-1.752$ & 2.781 & 21 & 0.011 \\
\hline Sesudah & 7 & 5.682 & 1.875 & & & & \\
\hline
\end{tabular}

Berdasarkan tabel 3 ini menunjukkan rata-rata interdialytic weight gain atau kepatuhan pembatasan cairan sebelum dilakukan hasil uji statistik didapatkan $p$ value $=$ 0.001, maka dapat disimpulkan bahwa ada perbedaan antara interdialytic weight gain 
atau kepatuhan pembatasan cairanperlakuan adalah $6.685 \%(\mathrm{SD}=0.455)$, sedangkan rata-rata interdialytic weight gain atau kepatuhan pembatasan cairan setelah perlakuan adalah $5.682 \%(\mathrm{SD}=1.875)$. Sesudah dilakukan edukasi dengan pendekatan spiritual berbasis video.

Tabel. 4

Seleksi Bivariat Usia, Dukungan Keluarga dan Tingkat Pendidikan

\begin{tabular}{cc}
\hline Variabel & $\mathrm{p}$ Value \\
\hline Usia & 0,364 \\
Dukungan Keluarga & 0.047 \\
Tingkat Pendidikan & 0.949
\end{tabular}

Berdasarkan tabel 4 didapatkan bahwa hasil analisa seleksi bivariat untuk variabel usia, dukungan keluarga, tingkat pendidikan terhadap IDWG didapatkan variabel usia dengan $p$ value $=0.364$, untuk variabel dukungan keluarga $p$ value $=0,047$ sedangkan variabel tingkat pendidikan $p$ value $=0,949$, dimana untuk melanjutkan ketahapan pemodelan multivariat variabel harus memiliki $p$ value $<0,25$. Hasil analisa seleksi bivariat ini variabel yang memenuhi syarat untuk melanjutkan ke tahap pemodelan multivariat ialah variabel dukungan keluarga.

\section{PEMBAHASAN}

Analisis Univariat

Hasil penelitian menunjukkan bahwa klien yang mengalami end stage renal disease yang menjalani terapi hemodialisa lebih dominan terjadi pada jenis kelamin laki-laki yaitu sebanyak 12 klien (54.5\%). Sedangkan perempuan sebanyak 10 klien $(45.5 \%)$. Hasil penelitian ini sejalan dengan penelitian yang dilakukan oleh Sumigar, dkk (2015) dengan judul hubungan dukungan keluarga dengan kepatuhan diet pada klien end stage renal disease dimana jenis kelamin laki-laki lebih banyak dengan jumlah 34 klien $(65,4 \%)$ dan perempuan 18 klien $(34,6 \%)$. Hasil penelitian ini juga diperkuat oleh penelitian Rompas, dkk (2013) bahwa klien End Stage Renal Disease sebagian besar terjadi pada laki-laki yaitu sebanyak 26 klien $(65 \%)$ dan perempuan sebanyak 14 klien $(35 \%)$.

Hasil penelitian ini sejalan dengan penelitian yang dilakukan oleh Sumigar, dkk (2015), dengan judul hubungan dukungan keluarga dengan kepatuhan diet pada klien End Stage Renal Disease. Dimana jenis kelamin laki-laki lebih banyak dengan jumlah 34 klien $(65,4 \%)$ dan perempuan 18 klien $(34,6 \%)$. Hasil penelitian ini juga diperkuat oleh penelitian Rompas, dkk (2013) bahwa klien end stage renal disease sebagian besar terjadi pada laki-laki yaitu sebanyak 26 klien (65\%) dan perempuan sebanyak 14 klien $(35 \%)$. Jenis kelamin laki-laki lebih memiliki persentase yang besar dibandingkan perempuan karena gaya hidup laki-laki yang berbeda dengan perempuan seperti merokok. Dimana merokok merupakan faktor resiko terjadinya berbagai penyakit seperti kardiovaskuler dan end stage renal disease (Hidayati, 2012).

Sedangkan hasil penelitian Sumigar, dkk (2015) menjelaskan dalam hal menjaga kesehatan biasanya kaum perempuan yang lebih menjaga kesehatan dibandingkan dengan laki-laki, pola makan laki-laki yang tidak teratur dan sebagian besar laki-laki suka mengkonsumsi minuman beralkohol serta pada laki-laki juga memiliki kadar kreatinin yang lebih tinggi dari pada perempuan sehingga memiliki resiko yang lebih 
tinggi untuk mengalami end stage renal disease. Penelitian lain juga mengatakan yaitu Istanti (2014) laki-laki memiliki kecendrungan yang lebih rentan terkena end stage renal disease karena pekerjaan laki-laki lebih berat dari perempuan serta end stage renal disease disebabkan juga karena laki-laki terlalu sering mengkonsumsi minuman suplemen.

Menurut peneliti responden dengan jenis kelamin laki-laki lebih memiliki resiko yang lebih besar untuk mengalami end stage renal disease karena pola dan gaya hidup laki-laki kurang baik dibandingkan dengan pola dan gaya hidup perempuan, dimana laki-laki mempunyai kebiasaan merokok, mengkonsumsi alkohol, mengkonsumsi minuman suplemen serta laki-laki memilki kadar kretinin yang lebih tinggi dari perempuan dimana hal ini dapat memperberat dari fungsi ginjal sebagai proses filtrasi, reabsorbsi, sekresi dan eksresi. hal ini jika tidak mendapatkan perhatian khusus akan menyebabkan responden laki-laki memiliki resiko mengalami end stage renal disease.

Hasil penelitian ini juga menunjukkan bahwa klien yang mengalami end stage renal disease yang menjalani terapi hemodialisa dilihat dari distribusi frekuensi tingkat pendidikan responden sebagian besar responden tingkat pendidikannya rendah yakni 12 klien $(54,5 \%)$ sedangkan yang berpendidikan tinggi yakni 10 klien (45,5\%). Hasil penelitian ini sejalan dengan penelitian yang dilakukan oleh Hanum, dkk (2015) dengan judul pengaruh pendidikan kesehatan secara individual tentang pembatasan asupan cairan terhadap pengetahuan pembatasan cairan dan IDWG klien hemodialisa. Dimana responden dengan tingkat pendidikan rendah berjumlah $24(80 \%)$ sedangkan responden dengan tingkat pendidikan tinggi berjumlah 6 (20\%). Secara umum seseorang yang memiliki tingkat pendidikan tinggi akan mempunyai pengetahuan luas dibandingkan dengan seseorang yang tingkat pendidikannya lebih rendah. Keyakinan biasanya diperoleh secara turun temurun dan tanpa adanya pembuktian terlebih dahulu, keyakinan ini dapat mempengaruhi pengetahuan seseorang baik keyakinan yang sifatnya positif maupun negatif (Notoadmojo, 2012).

Klien yang mengalami end stage renal disease dengan pendidikan lebih tinggi akan memiliki pengetahuan yang lebih luas sehingga memudahkan untuk mengontrol dirinya terutama dalam hal mengatasi masalah, memiliki rasa percaya diri yang tinggi serta mudah mengerti tentang apa yang dianjurkan petugas kesehatan sehingga akan membantu individu dalam membuat sebuah keputusan (Kamaluddin, 2009). Secara umum klien yang memiliki pendidikan lebih tinggi akan mempunyai pengetahuan yang lebih luas dibandingkan dengan klien dengan tingkat pendidikan lebih rendah. Semakin tinggi tingkat pendidikan seseorang, dia akan cenderung untuk berperilaku positif karena pendidikan yang diperoleh dapat meletakkan dasar-dasar pengertian dalam diri seseorang (Riyanto, 2011).

Menurut peneliti klien yang mengalami end stage renal disease sebagian kecil terjadi pada klien yang memiliki pendidikan tinggi dikarenakan semakin tinggi tingkat pendidikan seseorang akan semakin kritis, logis dan sistematis cara berpikirnya. sehingga orang yang memiliki tingkat pendidikan lebih tinggi tentunya dapat lebih menyadari dan menghindari faktor-faktor resiko yang dapat menyebabkan terjadinya end stage renal disease. sehingga klien yang memiliki tingkat pendidikan rendah akan lebih sulit untuk mengambil keputusan dalam hal mencegah dan menyadari faktorfaktor yang dapat menyebabkan terjadinya end stage renal disease.

Hasil penelitian menunjukkan rata-rata usia responden yang mengalami end stage renal disease dengan terapi hemodialisa adalah 44, 9 tahun dengan usia termuda 20 tahun dan yang tertua 63 tahun. Hasil penelitian ini sejalan dengan penelitian yang 
dilakukan Hidayati (2012) dimana rata-rata usia klien end stage renal disease yang menjalani terapi hemodialisa pada kelompok intervensi 42,17 tahun sedangkan pada kelompok kontrol 41,75 tahun.

Hasil penelitian ini juga diperkuat oleh penelitian Safitri, dkk (2012) dimana klien end stage renal disease yang menjalani hemodialisa berdasarkan distribusi usia didapatkan usia 36-50 tahun pada kelompok intervensi sejumlah 5 klien (50\%) sedangkan usia 36-50 tahun pada kelompok kontrol sejumlah 6 klien (60\%).Semakin bertambahnya usia fungsi ginjal juga semakin menurun, dimana setelah usia 40 tahun akan menyebabkan terjadinya penurunan laju filtrasi glomerulus secara progresif hingga umur 70 tahun yaitu kurang lebih 50 dari normalnya (Hanum dkk, 2015). Klien yang berada pada usia semakin tua maka akan berpeluang mengalami penyakit salah satunya end stage renal disease (Rompas, 2013).

Menurut peneliti klien yang menjalani end stage renal disease yang menjalani terapi hemodialisa dengan usia rata-rata 44,9 tahun dapat menyebabkan fungsi ginjal terus menurun seiring dengan penambahan usia sehingga akan terjadi penurunan GFR yang menyebabkan keadaan dimana ginjal tidak mampu mempertahankan keseimbangan cairan dan elektrolit yang merupakan manifestasi dari penurunan fungsi ginjal yang akan berdampak pada klien mengalami end stage renal disease .

\section{Analisis Bivariat}

Hasil analisis menunjukkan rata-rata interdialytic weight gain atau kepatuhan pembatasan cairan sebelum dilakukan edukasi dengan pendekatan spiritual adalah 6,685 $\%(\mathrm{SD}=0,455)$, sedangkan hasil analisis menunjukan rata-rata interdialytic weight gainmengalami penurunan sesudah dilakukan edukasi dengan pendekatan spiritual berbasis videodengan rata-rataadalah 5,682 \% (SD = 1,875). Hasil uji statistik didapatkan $p$ value $=0,011$ kurang dari nilai $\alpha=0,05$, sehingga dapat disimpulkan bahwa ada perbedaan antara interdialytic weight gain atau kepatuhan pembatasan cairan sebelum dan sesudah dilakukan edukasi dengan pendekatan spiritual berbasis video. Hasil penelitian ini sejalan dengan penelitian yang dilakukan oleh Hanum, dkk (2015) dengan menggunakan uji $T$ Dependent diperoleh $p$ value $(0,000),<\alpha(0.05)$ bahwa ada perbedaan pengetahuan tentang pembatasan asupan cairan dan IDWG setelah diberikan pendidikan kesehatan. Sedangkan hasil penelitian yang dilakukan oleh Hidayati (2012), dengan $p$ value (0.0003) dimana ada pengaruh dari edukasi berupa konseling terhadap penurunan interdialytic weight gain.

Hasil penelitian ini membuktikan hipotesis penelitian yang menyatakan bahwa terdapat perbedaan yang bermakna antara kepatuhan pembatasan cairan sebelum dan setelah mendapatkan edukasi dengan pendekatan spiritual berbasis video sehingga dapat disimpulkan bahwa edukasi dengan pendekatan spiritual berbasis video dapat meningkatkan kepatuhan pembatasan cairan pada klien end stage renal disease yang menjalani terapi hemodialisa. Edukasi merupakan suatu proses dimana proses ini mempunyai masukan dan keluaran di dalam suatu proses edukasiyang menuju tercapainya tujuan pendidikan berupa perubahan prilaku (Notoadmojo, 2012). Edukasi juga bertujuan untuk meningkatkan pengetahuan, kesadaran, kemauan dan kemampuan klien untuk hidup sehat dan aktif berperan serta dalam upaya kesehatan (Ali, 2010). Sedangkan spiritual merupakan bagian edukasi yang memberikan pengaruh kuat pada kepribadian seseorang, berpegang teguh dalam pribadi dan tingkah laku kepada ahklak mulia dengan selalu konsisten, memiliki jiwa yang optimis dengan selalu meminta bantuan kepada yang maha kuasa (Sakir, 2015). 
Oleh karena itu menurut peneliti edukasi dengan pendekatan spiritual akan mampu membuat seorang klien mampu dalam mengambil keputusan untuk patuh terhadap pembatasan cairan serta menumbuhkan sifat konsisten, optimis serta mampu beradaptasi terhadap terapi dan kondisi yang sedang dijalaninya. Hal lain diungkapkan oleh Suratih, dkk (2014) bahwa sebuah kegiatan spiritual akan memiliki dampak yang positif termasuk untuk meningkatkan kemampuan beradaptasi disaat seseorang sedang sakit. Kesehatan seseorang tergantung pada keseimbangan faktor fisik, psikologis, spiritual serta proses penyembuhan sering terjadi dengan adanya kepercayaan atau spiritual sehingga kepercayaan dan harapan individu akan mempengaruhi kesejahtraan fisik dan psikologis seseorang (Potter, Perry, 2010). Sejalan dengan teori Lubis yang menyatakan bahwa agama atau spiritual mempunyai makna yang penting bagi manusia karena iman dapat berfungsi sebagai penghibur dikala duka, menjadi sumber kekuatan batin pada saat menghadapi kesulitan, pemicu semangat dan harapan, pemberi sarana aman karena merasa selalu berada dalam lindungan-Nya, penghalau rasa takut karena merasa selalu dalam pengawasan-Nya, tegar menghadapi masalah karena selalu ada petunjuk melalui firman-firman-Nya, menjaga kemuliaan moral dan berprilaku baik terhadap lingkungan sebagaimana dicontohkan para rasul-Nya (Herliawati dkk, 2014).

Menurut Peneliti edukasi dengan menggunakan pendekatan spiritual mampu merubah perilaku seseorang untuk patuh terhadap pembatasan cairan karena dilandasi oleh rasa percaya diri dan optimis serta hal ini merupakan sesuatu yang baru bagi klien sehingga menumbuhkan antusias dan motivasi yang tinggi untuk mengetahui, mempelajari dan menerapkan edukasi dengan pendekatan spiritual dalam menjalani kehidupan mereka sehari-hari sebagai seorang penderita end stage renal disease. Hal ini diungkapkan sebagian besar klien dalam penelitian ini, serta dapat dilihat dari partisipasinya dalam mengikuti edukasi dengan pendekatan spiritual berbasis video. Sikap positif tersebut memotivasi klien untuk belajar pengetahuan baru yang diberikan. Kepatuhan pembatasan cairan juga dapat dipengaruhi oleh karena adanya beberapa faktor yang membentuk prilaku antara lain: karena adanya niat dari klien untuk melakukan keterampilan yang belum pernah dilakukannya, adanya motivasi dari klien untuk melakukan edukasiyang telah diberikan yang dilandasi atas keyakinan spiritual mereka setelah mendengarkan dan memahami ayat suci al-quran yang menjelaskan perintah untuk patuh terhadap proses pengobatan atau perawatan termasuk patuh terhadap pengontrolan asupan cairan, serta adanya kebebasan yang diberikan kepada klien untuk mengambil keputusan.

Menurut Notoadmodjo (2012) mengatakan bahwa sebelum seseorang mengadopsi sesuatu yang baru, didalam diri terjadi secara berurutan yakni: 1) awareness (kesadaran), dimana orang tersebut menyadari atau mengetahui terlebih dahulu terhadap objek stimulus; 2) interest, dimana orang sudah mulai tertarik dengan stimulus tersebut; 3) evaluation, orang mulai menimbang baik buruknya stimulus tersebut; 4) trial, orang sudah mulai mencoba perilaku baru dan 5) adapatasi orang yang telah berprilaku baru sesuai dengan pengetahuan, kesadaran dan sikapnya terhadap stimulus. Oleh karena itu, setelah klien melalui proses edukasi yang telah dilalui harapannnya kepatuhan pembatasan cairan dapat menjadi lebih baik.

Menurut peneliti, banyaknya klien yang mengalami ketidakpatuhan klien dalam mengontrol intake cairan, karena kurangnya informasi tentang pembatasan asupan cairan, kurangnya keyakinan dan motivasi dalam diri klien terkait dengan keberhasilan dari informasi yang diberikan oleh tenaga kesehatan untuk membatasi asupan cairan karena pemberian informasi tidak memberikan sentuhan rohani atau spiritual yang dapat 
meningkatkan keyakinan dari sisi kepercayaan klien yang nantinya dapat memotivasi klien untuk patuh dalam membatasi asupan cairan. Dalam hasil penelitian ini, didapatkan bahwa rata-rata klien patuh terhadap pembatasan asupan cairan. Akan tetapi masih terdapat klien yang tidak patuh terhadap pembatasan asupan cairan oleh karena itu, peneliti membuat suatu sistem yang didasarkan pada peran perawat dalam memenuhi kebutuhan akan perawatan diri klien. Perencanaan disusun berdasarkan supportive-educative. Hal ini dikarenakan secara fisik klien cukup mampu melaksanakan aktivitas secara mandiri, akan tetapi klien membutuhkan bantuan untuk pembuatan keputusan, mengendalikan perilakunya dan mendapatkan pengetahuan dan keterampilan. Sehingga dengan adanya supportive educative yang diberikan oleh peneliti, maka klien diharapkan mampu melakukan perawatan terhadap dirinya termasuk dalam mengatasi ketidakpatuhan dalam pembatasan asupan cairan.

Untuk variabel confounding seperti usia terhadap kepatuhan pembatasan cairan dengan $p$ value $=0,364$. bahwa secara analisis statistik tidak ada hubungan antara usia dengan kepatuhan pembatasan asupan cairan klien end stage renal disease yang menjalani terapi hemodialisa. Hal ini sejalan dengan penelitian Kamaluddin, Rahayu (2009) tentang faktor-faktor yang mempengaruhi kepatuhan asupan cairan dengan $p$ value $=0,100$ yang berarti tidak ada pengaruh antara usia klien dengan kepatuhan dalam mengurangi asupan cairan. Sedangkan hasil penelitian Hidayati (2012) diperoleh $p$ value $=0,051$ sehingga diperoleh tidak ada hubungan yang signifikan antara usia dan penurunan IDWG. Menurut peneliti usia yang lebih tua belum tentu akan lebih patuh terhadap pembatasan asupan cairan bila tidak ditunjang oleh pengetahuan dan informasi sebagai faktor sarana terjadinaya perubahan prilaku dan kurangnya pengalaman yang pernah dialami klien terkait dengan pembatsan asupan cairan sehingga kepatuhan dalam pembatasan asupan cairan pada berbagai usia merupakan masalah yang sama. Seperti yang diungkapkan oleh Kamaluddin, Rahayu (2009) yang menunjukkan bahwa ketaatan terhadap aturan pengobatan pada anak-anak dan remaja merupakan persoalan yang sama dengan ketaatan pada klien dewasa.

Sedangkan untuk variabel dukungan keluarga menunjukkan ada hubungan dukungan keluarga dengan kepatuhan pembatasan cairan klien end stage renal disease yang menjalani terapi hemodialisa, dengan nilai ( $p$ value $=0,047 ; \alpha=0,05$ ) dengan $\mathrm{R}$ Square 0.183. Hasil penelitian sejalan dengan hasil penelitian yang dilakukan oleh Sumigar, dkk (2015) yang mengatakan dukungan keluarga berhubungan dengan dengan kepatuhan diet pada klien end stage renal disease dengan nilai $p$ value $=0,001$. Hasil penelitian Kamaluddin, dkk (2009) mengatakan hal yang sama dimana perbedaan antara keterlibatan keluarga pada penderita patuh dengan yang tidak patuh dengan $p$ value $=$ 0.000 dimana diperoleh hasil ada pengaruh keterlibatan keluarga dengan kepatuhan klien dalam mengurangi asupan cairan. Dalam hal ini keterlibatan keluarga dapat diartikan sebagai suatu bentuk hubungan sosial yang bersifat menolong dengan melibatkan aspek perhatian, bantuan dan penilaian dari keluarga.

Dukungan keluarga merupakan suatu bentuk perhatian, dorongan yang didapatkan klien dari orang lain melalui hubungan interpersonal yang terdiri dari perhatian, emosional dan penilaian. Dukungan keluarga yang baik sangat berpengaruh dalam menentukan keyakinan dan nilai kesehatan serta mempengaruhi proses penyembuhan lewat pemberian perhatian, rasa dicintai, dihargai dapat menjadi motivasi yang besar untuk patuh dalam menjalankan diet (Sumigar dkk, 2015). Selain itu keluarga juga merupakan faktor yang berpengaruh dalam menentukan program pengobatan, derajat 
dimana seseorang terisolasi dari pendampingan orang lain, isolasi sosial secara negat if berhubungan dengan kepatuhan (Kamaluddin, dkk, 2009).

Dukungan keluarga dalam hal ini memberikan motivasi, perhatian, mengingatkan untuk selalu melakukan pembatasan asupan cairan sesuai dengan anjuran tim medis. Dukungan sosial juga mempunyai hubungan yang positif yang dapat mempengaruhi kesehatan individu dan kesejahteraannya atau dapat meningkatkan kreativitas individu dalam kemampuan penyesuaian yang adaptif terhadap stres dan rasa sakit yang dialami (Sari, 2009). Menurut peneliti dukungan keluarga merupakan hal yang sangat penting untuk menciptakan perilaku yang patuh terhadap pembatasan cairan karena mendapatkan perhatian secara langsung dari keluarga, merasa selalu dicintai, dihargai sehingga akan menumbuhkan keyakinan dan motivasi untuk patuh terhadap proses penyembuhan dan perawatan yang sedang dijalani oleh klien.

Untuk variabel tingkat pendidikan hasil analisis bivariat menunjukkan tidak ada hubungan tingkat pendidikan dengan kepatuhan pembatasan cairan klien end stage renal disease dengan nilai ( $p$ value $=0,949 ; \alpha=0,05$ ). Hasil penelitian ini sejalan dengan hasil penelitian Hidayati (2012) yang mengatakan tidak ada hubungan yang signifikan antara edukasi dengan penurunan IDWG atau ketidakpatuhan dalam pembatasan cairan dengan $p$ value $=0,630$. Tingkat pendidikan tidak mempengaruhi perubahan perilaku, hal ini tergantung terhadap ketersediaan sumber informasi yang ada. Petugas kesehatan memiliki peranan yang sangat penting terhadap perubahan perilaku klien dengan memberikan informasi yang jelas berupa penyuluhan kesehatan (Hidayati, 2012). Menurut Istanti (2014) tidak ada hubungan yang signifikan antara tingkat pendidikan dengan kejadian IDWG dengan $p$ value $=0,808$. hal ini memperlihatkan bahwa kemampuan melakukan perawatan mandiri selama hemodialisa terutama pengelolaan tidak hanya dipengaruhi tingkat pendidikan akan tetapi dihasilkan dari interaksi pengetahuan, sikap dan tindakan klien dalam pengelolaan cairan, diet yang diperoleh dari pengalaman sendiri atau sumber lain seperti media.

Secara statistik dari faktor confounding usia, dukungan keluarga dan tingkat pendidikan hanya dukungan keluarga yang memiliki pengaruh terhadap kepatuhan pembatasan cairan atau penambahan berat badan diantara dua waktu hemodialisa dengan $p$ value 0,047 . Sedangkan variabel usia dan tingkat pendidikan didapatkan nilai $p$ value 0,364 dan 0,949 sehingga bisa disimpulkan variabel usia dan tingkat pendidikan tidak memiliki pengaruh terhadap kepatuhan pembatasan cairan. Hasil statistik ini memperkuat bahwa kepatuhan pembatasan asupan cairan lebih banyak disebabkan oleh adanya intervensi berupa edukasi dengan pendekatan spiritual berbasis video yang dikontrol juga oleh faktor confounding berupa dukungan keluarga.

\section{SIMPULAN}

Terdapat perubahan rata-rata interdialytic weight gain atau kepatuhan pembatasan cairan sesudah edukasi dengan pendekatan spiritual berbasis video lebih rendah dibanding dengan rata-rata interdialytic weight gain atau kepatuhan pembatasan cairan sebelum edukasidengan pendekatan spiritual berbasis video pada klien end stage renal disease yang menjalani hemodialisa.

Ada perbedaan nilai rata-rata interdialytic weight gain atau kepatuhan pembatasan cairan pada klien end stage renal disease yang menjalani hemodialisa sesudah dilakukan pendidikan kesehatan dengan pendekatan spiritual berbasis video ( $p$ value= 0,011). 
Untuk variabel confounding ada hubungan dukungan keluarga dengan interdialytic weight gainataukepatuhan pembatasan cairan dengan $p$ value $=0,047$.

\section{SARAN}

Penentu kebijakan di rumah sakit maupun layanan kesehatan baik milik pemerintahan maupun swasta agar dapat mengembangkan protap intervensi keperawatan dalam pelaksanaan manajemen konservatif klien dengan interdialytic weight gain dengan cara menerapkan edukasi dengan pendekatan spiritual berbasis video pada perawatan klien end stage renal disease yang menjalani hemodialisa dengan gangguan kepatuhan pembatasan cairan atau peningkatan interdialytic weight gain. Untuk pengembangan penelitian diharapkan dilakukan penelitian lebih lanjut dengan menambah variabel-variabel penelitian dengan cara mengkombinasikan edukasi dengan pendekatan yang lain dan media yang berbeda yang dapat meningkatkan kepatuhan pembatasan cairan klien end stage renal disease yang menjalani terapi hemodialisa serta perlu dilakukan penelitian terhadap faktor-faktor confounding lainya seperti adekuasi, pengetahuan, informasi, keyakinan, sikap, dan lama menjalani hemodialisa untuk mengetahui variabel mana saja yang memiliki pengaruh terhadap masalah kepatuhan pembatasan cairan klien end stage renal disease yang menjalani terapi hemodialisa, tentunya dengan jumlah sampel yang lebih banyak.

\section{DAFTAR PUSTAKA}

Ali, Z. (2010). Dasar-Dasar Pendidikan Kesehatan Masyarakat dan Promosi Kesehatan. Jakarta: Trans Info Media

Blacks, M.J. \& Hawk, H.J. (2014). Keperawatan Medikal Bedah: Manajemen Klinis untuk Hasil yang Diharapkan. (8 ed ). Jakarta: Salemba Medika

Brunner. \& Suddarth's. (2005). Textbook of Medical Surgical Nursing. Lippincott: Williams Wilkins

Grassley, S. J. (2012). The Lived Experience of Giving Spiritual Care: a Phenomenological Study of Nephrology Nurses Working in Acute and Chronic Hemodialysis Settings. Nephrology Jurnal, 39(6)

Hanum, R. Nurchayati, S. Hasneli, N.Y. (2015). Pengaruh Pendidikan Kesehatan Secara Individual tentang Pembatasan Asupan Cairan terhadap Pengetahuan tentang Pembatasan Cairan dan IDWG (Interdialytic Weight Gain) pada Klien Hemodialisis. Jom, 2(2)

Hariyadi, S. (2012). Video Sebagai Media Layanan Bimbingan dan Konseling. Yogyakarta

Herliawati., Maryatun, S., Herawati, D. (2014). Pengaruh Pendekatan Spiritual Terhadap Tingkat Kesepian pada Lanjut Usia di Panti Sosial Tresna Werdha Warga Tama Kelurahan Timbangan Kecamatan Indralaya Utara. Jurnal Keperawatan Sriwijaya, 1(1), ISSN No 23555459

Hidayati, S. (2012). Efektifitas Konseling Analisis Transaksional tentang Diet Cairan terhadap Penurunan Interdialytic Weight Gain (IDWG) Pasien Gagal Ginjal Kronis yang Menjalani Hemodialisa di Rumah Sakit Umum Daerah Kardinah. Jakarta: Tesis

Hidayati, W. (2013). Metode Perawatan Pasien Gangguan Sistem Perkemihan Aplikasi Konsep Orem "Self Care Defisit" dan Studi Kasus. Jakarta: Penadamedia Group 
Istanti, P.Y. (2014). Hubungan antara Masukan Cairan dengan Interdialytic Weight GAINS (IDWG) pada Klien Chronic Kidney Diseases di Unit Hemodialisis Rs Pku Muhammadiyah Yogyakarta. Profesi, 10 / September 2013 - Februari 2014

Kamaluddin, R. \& Rahayu, E. (2009). Analisis Faktor-Faktor yang Mempengaruhi Kepatuhan Asupan Cairan pada Klien Gagal Ginjal Kronik dengan Hemodialisis di RSUD Prof. Dr.Margono Soekarjo Purwokerto. Jurnal Keperawatan Soedirman (The Soedirman Journal of Nursing), 4(1)

Kozier, B. ERB, G. Berman, A. Snyder, J.S. (2011). Buku ajar Fundamental Keperawatan, Konsep, Proses, \& Praktik. (7 ed ). Vol 2. Jakarta: EGC

Kugler. (2005). Nonadherence with Diet and Fluid Restrictions among Adults Having Hemodialysis. Journal of Nursing Scholarship, 37(1)

Notoatmodjo, S. (2012). Metodologi Penelitian Kesehatan. Edisi Revisi. Jakarta: Rineka Cipta

Nursalam, \& Effendi, F. (2008). Pendidikan dalam Keperawatan. Jakarta: Salemba Medika

Pernefri. (2012). 5th report of indonesian renal registry. (online). http://www.Pernefriinasn.org/Laporan/4th\%20Annual\%20Report\%20Of\%20IRR \%202011.pdf. Diakses 25 Januari 2016

Potter, A.P. \& Perry, G.A. (2010). Fundamental of Nursing. Concepts, Process and Practice. $\left(7^{\text {th }} \mathrm{ed}\right)$. Imprint of ElsivierInc: Mosby

Reams. \& Elder, V. (2003). Dry weight: To Be Set or no to Be That is a Good Question. Nephrology Nursing Journal

Riskesdas. (2013). Badan Penelitian dan Pengembangan Kesehatan Kementerian Kesehatan RI. Jakarta. (online). http://www. depkes.go.id /resources/ download /general/Hasil\%20Riskesdas\%202013.pdf. Diakses 25 Januari 2016

Riyanto, W. (2011). Hubungan antara Penambahan Berat Badan di Antara Dua Waktu Hemodialisis (Interdialysis Weight Gain) terhadap Kualitas Hidup Klien Penyakit Ginjal Kronik yang Menjalani Terapihemodialisis di Unit Hemodialisa Ip2k RSUP Fatmawati Jakarta. Jakarta: Tesis

Rompas, B.A. Tangka, J. Rotti, J (2015). Hubungan Kadar Hemoglobin dengan Kualitas Tidur Pasien Penyakit Ginjal Kronik di Poli Ginjal dan Hipertensi Blu RSUP Prof. Dr. r. d. Kandou Manado. Ejournal keperawatan (e-Kp), 1(1). Agustus 2013

Safitri. Aminoto, C. Asti, A.D. (2012). Pengaruh Hypnotheraphy terhadap Kepatuhan Diit Cairan pada Pasien Gagal Ginjal Kronis Rawat Jalan di Instalasi hemodialisa rs pku muhammadiyah gombong. Jurnal ilmiah kesehatan keperawatan, 8(3). Oktober 2012

Sakir, M. (2015). Pesantren Sebagai Basis Pendidikan Spiritual dalam Pembentukan Karakter Jati Diri Manusia. Wonosobo: Unsiq. Cendekia, 13(2)

Sari, K.L. (2009). Faktor-Faktor yang Berhubungan dengan Kepatuhan dalam Pembatasan Asupan Cairan pada Klien Gagal Ginjal Kronik yang Menjalani Terapi Hemodialisis di Ruang Hemodialisa RSUP Fatmawati Jakarta. Jakarta: Skripsi.

Smeltzer, S.C. \& Bare, B.G. (2008). Brunner and Suddarth's Teksbook of Medikal Surgical Nursing. Philadelphia Williams dan Wilkins

Sumigar, G. Rompas, S. Pondaag, L. (2015). Hubungan Dukungan Keluarga dengan Kepatuhan Diet pada Klien Gagal Ginjal Kronik di Irina C2 dan C4 RSUP Prof. Dr. r. d. Kandou Manado. Ejournal Keperawatan (e-Kep), 3(1) 
Suratih, K. Suranah. R. (2014). Pengaruh Bimbingan Spiritual Islami terhadap Kualitas Hidup Klien Hemodialisis di RSUD Kabupaten Semarang. Prosiding Konferensi Nasional II PPNI Jawa Tengah 2014

Walton, J. (2002). Finding a Balance: a Grounded Theory Study of Spirituality in Hemodialysis Patients/Commentary. Nephrology Nursing Journal, 29(5) ProQuest Nursing \& Allied Health Source pg. 447 